\title{
Restoration of Degraded Gidan Waya Forest Reserve
}

\author{
Dogo Bitrus Ajeye \\ Department of Geography, Kaduna State College of Education, \\ Gidan Waya, Nigeria
}

Doi:10.5901/ ajis.2014.v3n7p146

\begin{abstract}
Land degradation is a matter of serious concern. Vast area of land all over the world has been converted into unproductive and degraded lands. Ecosystem restoration through plantation forest is the most effective technique to reclaim the degraded landscape. Measurement of slopes angles and correspondent rates of soil erosion were taken at different spots of cultivated slopes which have been occupied for particular period of time. This paper explores the impact of human activities as the main cause of land degradation and loss of biodiversity. The result indicated that cultivation on steeper slopes is more harmful and degradation is faster. Restoration of this area is possible when farmers receive environmental education through the planting of exotic tree species of Tectona grandis and G melina that grows faster in this region. The DPSIR (Driving force, Pressure, State, Impacts, Response) conceptual framework model is used to illustrate how degradation control could be more effective, tackling not only the drivers of change but also major developmental issues such as poverty and food insecurity.
\end{abstract}

Keywords: Land degradation, Restoration, Biodiversity loss, Cultivation, Land use.

\section{Introduction}

Land degradation is a long-term loss of ecosystem function and services, caused by disturbances from which the system cannot recover unaided. It blights a significant proportion of the land surface, and as much as one-third of the world's population-poor people and poor countries suffer disproportionately from its effects. Established evidence links land degradation with loss of biodiversity and climate change, both as cause-and-effect, (Bai and Dent, 2013).

According to the United Nations Convention to Combat Desertification (UNCCD) in 2005, over 250million people were directly affected by land degradation, this figure has since double itself by 2013. In addition, some one billion people in over 100 countries are at risk. These people include many of the world's poorest, most marginalized and politically weak citizens.

The Gidan Waya reserve is one among the several reserves areas established by the Federal Government in 1964 with a sole aim of preserving biodiversity in the hinterlands. Population increase has led to encroachment and destruction of the vegetation for farming, efforts made by local authorities to stop cultivation falls on deft ears even when they were threatened. Continuous cultivation on the steep slopes of this reserve has led to land degradation and loss of biodiversity, especially the macro-fauna and flora over a period of about 25 to 30 years of occupation.

Any effort at restoring this ecosystem requires a full understanding of the ecological deficiencies in the ecosystem, a defined course of scientific study through experimental management, and the development of a programme for carrying out restoration (Apfelbaum and Chapman, 1994, Bradshaw, 1995).

In order to restore this ecosystem, there is a need to identify some plants and animal species that existed before occupation and interference by human activities in this area. Among the common macro-fauna includes the disappearance of Red Monkeys, Baboons, Long-tail Fruit-eating Monkeys, Rock Pythons, Grass-cutters, Fresh water dwelling species of Cobra Snakes etc. Among the macro-flora that has been completely destroyed include the mahogany trees and all-log bearing trees that naturally grow in this environment were completely harvested or destroyed. The continual use of herbicides especially the broad spectrum herbicides and the surface grass crusher herbicides of Paraquat Dichlorides has also led to the loss of grass species such as Adropogenea Hyparrhenia, Monocybium correstiforme in some areas and others at the verge of disappearance.

Restoration of degraded lands requires concerted efforts by authorities concern, finances and a long period of time for any given portion of a land to be restored back to its original state. Gisladottir and Stocking (2005) consider the magnitude and effects of land degradation, that they require global attention. They linked land restoration with poverty 
reduction, thus achieving the millennium development goals of ensuring environmental sustainability. They also reiterates that world leaders and the major multilateral development and environment institutions should all subscribe to the importance of land degradation, development, food security and poverty linkages (see table 1).

Table 1. Statements by world leaders and multilateral institutions on land degradation linkages with global development concerns.

\begin{tabular}{|c|c|}
\hline Statement & Source \\
\hline $\begin{array}{l}\text { (We need to) address the causes of } \\
\text { desertification in order to restore land and } \\
\text { to address poverty resulting from land } \\
\text { degradation. }\end{array}$ & $\begin{array}{l}\text { World Summit on Sustainable } \\
\text { Development, September } 2002\end{array}$ \\
\hline People care a lot of about their environment & $\begin{array}{l}\text { UNDP 2003: Human } \\
\text { development Report }\end{array}$ \\
\hline $\begin{array}{l}\text { Addressing land degradation (will) ......... } \\
\text { significantly to the Millennium }\end{array}$ & $\begin{array}{l}\text { Operational Program 15, contribute } \\
\text { Global Environmental facility, }\end{array}$ \\
\hline $\begin{array}{l}\text { Development Goals of reducing by half the } \\
\text { proportion of people in poverty by } 2015 \text { and } \\
\text { ensuring environmental sustainability. }\end{array}$ & December, 2003. \\
\hline $\begin{array}{l}\text { Land degradation is equally cause and effect of } \\
\text { poverty and it bears long term environmental } \\
\text { externalities .... to which people in marginal } \\
\text { lands are especially vulnerable. }\end{array}$ & $\begin{array}{l}\text { Klaus Topfer, executive } \\
\text { Director, UNEP (Foreword in } \\
\text { UNEP 2004). }\end{array}$ \\
\hline $\begin{array}{l}\text { Desertification ......contributes to food } \\
\text { insecurity, famine and poverty, and can give } \\
\text { rise to social, economic and political tensions } \\
\text { that can cause conflicts, further poverty and } \\
\text { land degradation. }\end{array}$ & $\begin{array}{l}\text { Kofi Anna, UN Secretary } \\
\text { General, } 17 \text { June, } 2004\end{array}$ \\
\hline $\begin{array}{l}\text { Poverty and desertification are closely linked. } \\
\text { Two-thirds of the world's hungry people live } \\
\text { in rural areas of developing countries. }\end{array}$ & $\begin{array}{l}\text { Secretariat, UN convention to } \\
\text { Combat Desertification, } 1^{\text {st }} \\
\text { June, } 2004\end{array}$ \\
\hline
\end{tabular}

Source: DFID, 2004

This paper therefore seeks to examine the harmful effects of land use processes that has affected the ecosystem and ways to restore its depleting soil resources and vegetation which provides habitat to both micro and macro organisms.

\section{The Study Area}

Located at the north - eastern parts of Jema'a Local Government Area and southern part of Kaura Local Government area of Kaduna State, Gidan waya reserve has an approximate total land area of about $50 \mathrm{~km}^{2}$. The area is situated between longitude $08^{\circ} 22^{\prime \prime} \mathrm{E}$ and latitude $09^{\circ} 32^{\prime \prime} \mathrm{N}$.

The initial vegetation of the study area was influenced by the micro - climate, topography and the high amount of rainfall which is both convectional and orographic because of the southern plateau escarpment which bordered the area to the north, (see fig. 1a, 1b). Because of the high amount of rainfall, the vegetation shares similar characteristics with a tropical rainforest vegetation. Today however, what is left behind is an open landscape with scattered trees, shrubs and variety of grasses.

Rainfall in this area is characterized by a single maximum with a peak in August. The mean annual rainfall total ranges from $1400 \mathrm{~mm}$ to $2500 \mathrm{~mm}$ slightly higher than the surrounding areas. Temperatures are generally high with an annual average of $30^{\circ} \mathrm{C}$, minimum temperature may fall to $15^{\circ} \mathrm{C}$ during the Hamattan period (December to January), while maximum temperature may rise to about $42^{\circ} \mathrm{C}$ between the February and early April, which is the hottest period.

The area is a major watershed with a lot of streams taking their source from the steep slopes and draining southwards into major rivers. 


\section{Research Problem}

Land degradation generally signifies that temporary or permanent decline in the productive capacity of the land. The UN/FAO (2005) defined land degradation as "the aggregate diminution of the productive potential of the land, including its major uses (rain-fed, arable, irrigated, range land, and forest), its farming systems (e.g. smallholders subsistence) and its value as an economic resource".

Continuous slash-and-burn method of land clearing for cultivation in the dry season and the use of herbicides in the rainy season, continuous fuel wood harvest, continuous animals grazing and cultivation on steep slopes has continue to deplete both the soil, water and vegetation resources without any visible restoration process put in place either by local authorities or the land users. If this trend continue, in a few years to come there would be food shortages, increased degradation and unproductive lands, communal clashes and restoration will equally become very difficult.

\section{Purpose of the Study}

The purpose of this study is to examine landscape restoration of degraded Gidan Waya Reserve in Jema'a Local Government Area of Kaduna State. In order to achieve the desired objective, the study seeks to:

a. Determine the extent of landscape degradation and its impacts on crop productivity.

b. Examine the effects of deforestation on soil erosion, streams sudation/disappearance and loss of soil fertility.

c. Examine ways of restoring the degraded landscape by means of improve cultivation methods, afforestation or restrictions (preservation) by local authorities to restore the ecosystem.

\section{Significance of the Study}

Afforestation programme is one among the important ways of checking land degradation and to conserve nonexpandable soil resources in view to increasing land productivity - to meet the demand of an ever increasing world population.

However, very little researches have been conducted in this part of the country to find out the effects of afforestation in regenerating soils that have suffered man mis-management land use practices such as permanent cultivation, overgrazing, continuous fuel wood harvest etc.

Therefore, this study would provide data and information for further studies that may share relevance to this work.

\section{Review of Related Literature}

Land degradation generally signifies the temporary or permanent decline in the productive capacity of the land (UN/FAO, 2005). It is "the aggregate diminution of the productive potential of land, including its major uses (rain-fed, arable, irrigated, rangeland, forest), its farming systems (e.g. small holder subsistence) and its value as an economic resource", (Bai and Dent, 2013).

Most of the degradation is due to soil erosion and biodiversity loss in the less populated areas, while water shortages, soil depletion and soil pollution are most common in the most agricultural areas, (Nachtergaele and Petri, 2010). The definition given above agrees with the situation of the Gidan Waya reserve whereby the productive capacity of the land continue to decline with time and this mainly as a result of soil erosion and biodiversity loss due to habitat destruction.

The natural ecosystem of this area was self sustaining despite the annual bush fires that characterized this environment, man's activities especially slash-and-burn clearance of forest for cultivation, hunting, continuous fuel wood harvest, continuous animal grazing and other forms of land use are observes as the identifiable cause of land degradation in Gidan Waya reserve.

In the past, increasing food needs have mainly been met by clearing and irrigating more land, converting more natural forests to agriculture, diverting more water resources, using improved variety and applying more fertilizers, these options are narrowing. (Arnalds, 2008). He also stated that the global community will be unable to achieve goals of food and water security and meet its G.H.G. emission targets without a major improvement in conservation and restoration of the world's soil resources.

Bradshaw (1995), believes that true restoration of degraded ecosystem may be unrealistic because it will take not less than 500 years to restore a forest ecosystem back to its original state and that it would not be possible to achieve an 
original soil profile in less than 5000 years, although the biological functions of a soil can perhaps be restored in less than 10 years.

Apfelbaum and Chapman (1994), opines that it is important to develop an appreciation for the necessity of restoration. Even after being informed about ecological degradation, some individuals are skeptical about the need to intervene. Farmer's response to decline of crop yield is an indication that land degradation does not make any meaning to them, concerted efforts to reclaim or restore the land is not their concern but rather, they shift their cultivation to other parts of the reserve where soil fertility is still high. The lack of will power in restoring degraded land in the study area is a serious problem and that in order to tackle this, there must be reorientation and environmental education given to them on the prospects of restoration.

Restoration of ecosystem requires the maintenance or alteration of composition and structural components by modifying processes. In any case, we argue restoration should follow nature's lead, not in order to slavishly recreate a nineteenth century ecosystem, but to restore an ecosystem's ability to respond to change.

One other way of restoring an ecosystem is re-afforestation: Dogo (1992) quantify the nutrient of 1 year to 25 years old teak (Tectona grandis, Linn P) plantations established by taungya system in Gambari forest and a 25 years old plantation established by direct plantation in Ibadan. At the end of it, he found out that the 25 years old teak carried as much biomass as the natural forest ecosystem. The high quality teak stands in Gambari forest raised by taungya at 15 years carry nearly as much nitrogen as the natural forest.

It is safe therefore, to conclude that restoration of degraded land is possible where there is willingness on the part of land users and local authorities to cooperate and work for the common good of today and the near future environmental sustainability.

\section{Conceptual Linkages for Land Degradation Control}

The DPSIR (Driving Force, Pressure, State, Impact Respond) model adopted by Gisladottir and Stocking (2004) has been adopted for this study as a policy tool to identify management options for a range of types of environmental problem. It captures the driving forces and pressures largely controlled by human activity and their effects on the environmental system and state of natural resources (fig. 3) for land degradation assessment and the identification of ways of control, the impacts and societal responses are especially important, enabling the assessment process to feed directly into measures for control of land degradation. The model has been adopted by the new multinational land Degradation Assessment in Dry lands project of the FAO, GEF (Global Environmental Facility) and UNEP, (FAO 2008) to identify suitable entry points for assessing the seriousness of degradation and for indentifying potential points of intervention.

\section{Land Degradation Control}

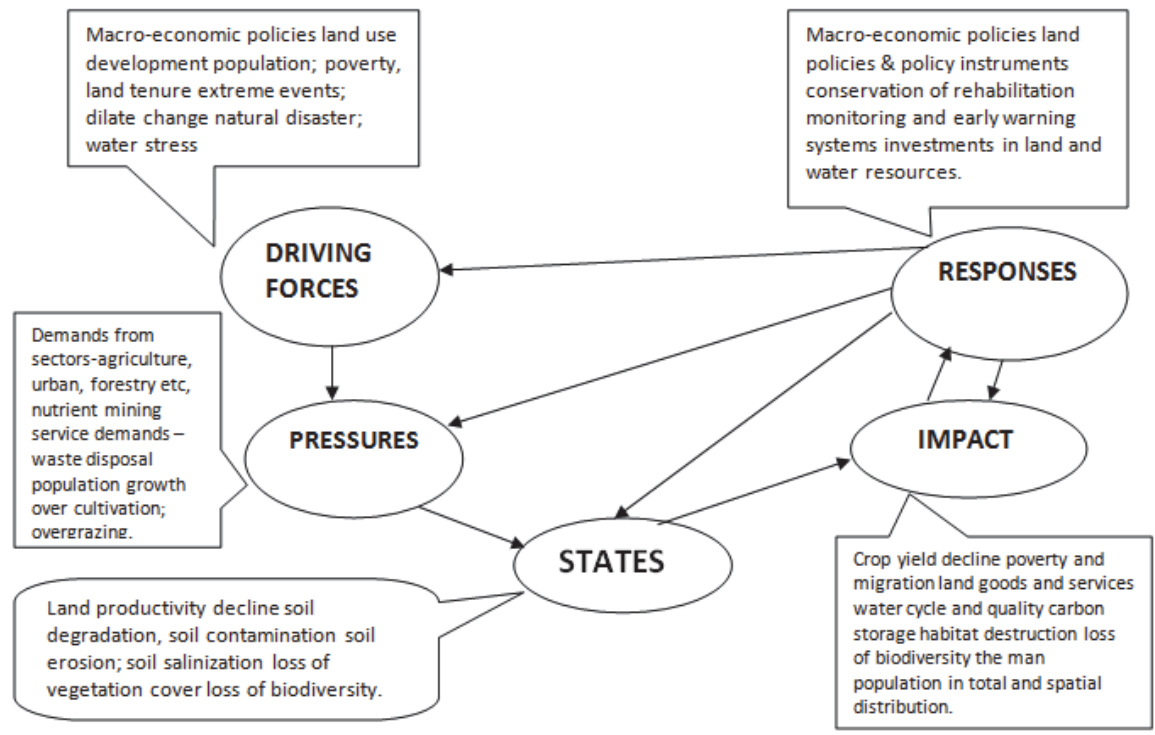

Fig. 3. The DPSIR (Driving Force, Pressure, State, Impacts, Response) conceptual Framework applied to potential land degradation control interventions. 
Previous attempts by local authorities to use direct threats on farmers to stop cultivation on this degraded reserve in the years 2004, 2007 and 2010 were unsuccessful. A proper understanding and adoption of this policy tool will provide a framework of control intervention because population pressure, poverty and unemployment is a driving force for farmers occupation of this reserve.

\section{Materials and Methods}

Gidan Waya reserve was established in 1964 by the Federal Government of Nigeria to preserve biodiversity in the interior hinterland climate of the study areas is tropical continental with a guinea savanna type of vegetation. Mean maximum and minimum temperature of $37^{\circ} \mathrm{C}$ and $15^{\circ} \mathrm{C}$ respectively, with average rainfall of $1750 \mathrm{~mm}$ provides and conducive atmosphere for plant growth. $95 \%$ precipitation occurs in rainy season. Vegetation before farmer's encroachment was very dense, near forest vegetation. Due to population increase; increasing poverty, unemployment and pressure due to limited farmlands, the local population encroached on this reserve areas turning it to farmlands and clearing off $80 \%$ of the vegetation. The present study was carried out in age series of human occupation and resultant effects of biodiversity loss, decline in crop yield and land degradation were examined.

Measurement of slope angles were taken using the GPS instrument (Garmin 101geko) at different spots of cultivated slopes of the reserve that has been cleared for the past $0-5$ years, $06-10$ years, $11-15$ years, and 16 years and above. The steepness of the slopes was observed to correspond with the rates of soil loss on areas deforested for cultivation.

Measurement of adjacent streams siltation was also taken using auger borrowing and measuring tape along stream channels. It should be noted that eroded materials are also transported by water down into surrounding rivers, thus our major focus is only the deposited material along stream channels adjacent to the cultivated slopes of the reserve.

Inventory of plants and animal species were also taken with the help of farmers to determine those that have been completely destroyed, remove or migrated out of the area due to habitat loss. Observation of crop yields were also taken on cultivated slopes based on age of occupation of $0-5$ years, $06-10$ years, $11-15$ years and 16 years and above. The crop yield was used as an index of soil fertility status and extent of land degradation.

\section{Results}

Results of measurement taken on variable used above were presented in table 2 and 3 below.

Table 2: Rates of soil erosion on areas with gentle slope of angle $<30^{\circ}$

\begin{tabular}{|c|c|c|c|c|}
\hline $\begin{array}{l}\text { Slope } \\
\text { Angle }\end{array}$ & $\begin{array}{l}\text { Age of land } \\
\text { occupation }\end{array}$ & $\begin{array}{l}\text { Rate of soil } \\
\text { erosion }\end{array}$ & $\begin{array}{c}\text { Average dept of soil } \\
\text { deposit in adjacent stream }\end{array}$ & Remarks \\
\hline \multirow{4}{*}{$<30^{\circ}$} & $0-5$ years & Low & $<10 \mathrm{~cm}$ & No physical signs of land degradation observed. \\
\hline & $6-10$ years & High & $05-15 \mathrm{~cm}$ & Little or no physical signs of land degradation observed. \\
\hline & $11-15$ years & High & $08-30 \mathrm{~cm}$ & $\begin{array}{l}\text { Physical evidence of land degradation. Decline in crop } \\
\text { yield and siltation of streams observed. }\end{array}$ \\
\hline & $\begin{array}{l}\text { 11years and } \\
\text { above }\end{array}$ & High & $08-60 \mathrm{~cm}$ & $\begin{array}{l}\text { Physical evidence of land degradation. Decline in crop } \\
\text { yield and siltation of streams observed. }\end{array}$ \\
\hline
\end{tabular}

Source: Researchers' Survey 2014

Table 2 above indicates that no physical signs of land degradation was observed on areas recently deforested $(0-5$ years) and there is little or no siltation of surrounding steams in these areas because of minimal erosion. However, areas that were cleared of vegetation over a much longer period of 11 years and above shows serious evidences of land degradation which is visible in terms of low-crop yields and siltation of adjacent streams. Soil accumulations over a period of time have resulted to the lowering of water-table and disappearance of stream-surface-flows.

\subsection{Rates of Soil Erosion on areas with Steep Slopes}

Results obtained on measurement of steep slopes are given in table 3 below. 
Table 3. Rates of Soil Erosion on Areas with Steep Slopes $>30^{\circ}$

\begin{tabular}{|c|c|c|c|l|}
\hline $\begin{array}{c}\text { Slope } \\
\text { Angle }\end{array}$ & $\begin{array}{c}\text { Age of land } \\
\text { occupation }\end{array}$ & $\begin{array}{c}\text { Rate of soil } \\
\text { erosion }\end{array}$ & $\begin{array}{c}\text { Average dept of soil } \\
\text { deposit in adjacent stream }\end{array}$ & Remarks \\
\hline \multirow{3}{*}{$>30^{\circ}$} & $0-5$ years & High & $<8 \mathrm{~cm}$ & No physical signs of land degradation observed. \\
\cline { 2 - 5 } & $6-10$ years & High & $05-25 \mathrm{~cm}$ & $\begin{array}{l}\text { Physical evidence of land degradation. Low crop yields, } \\
\text { siltation of stream adjacent to slopes observed. }\end{array}$ \\
\cline { 2 - 5 } & $\begin{array}{c}11 \text { years and } \\
\text { above }\end{array}$ & High & $08-45 \mathrm{~cm}$ & $\begin{array}{l}\text { Physical evidence of land degradation. Low crop yield, } \\
\text { siltation of stream adjacent to slopes observed. }\end{array}$ \\
\hline
\end{tabular}

Source: Researchers' Survey 2014

Table 3 above indicates that there is high rate of soil erosion on steep slopes of the reserve where trees have been cut down for cultivation, irrespective of the year of occupation. Though observable land degradation in terms of crop yield were observed, siltation of stream adjacent to steep slopes tends to be lower compared to areas with slopes less than $30^{\circ}$.

\subsection{Land Degradation Control and Landscape Restoration.}

Different approaches to land restoration have been applied in different part of the world. The International Atomic Energy Agency (1998) formulated strategies for environmental restoration of sites polluted with hazardous chemicals, solid wastes and gaseous emissions to serve as a policy guided toward restoration; this and many other projects by UN, FAO, UNEP etc, all work toward environmental restoration because our future depends on how well we manage one present day environmental resources.

Two approaches have been adopted for land restoration of the Gidan Waya reserve. The first approach is the use of local authorities and forestry officers to prevent farmers from cultivation in the reserve in order to allow the environment to restore itself through secondary succession. This approach failed simply because of population pressure, shortage of farmlands and poverty increase in this area. The second approach which is afforestation is considered by the researcher as the best method of restoring the ecosystem functioning.

Dogo (1992) observed that soil fertility in the semi-arid area of Northern Nigeria (Shika) was restored through afforestation with two species of trees-Eucalyptus and Pinus species. His analysis showed that the organic matter, nitrogen content, exchangedable cations, cation exchange capacity, $\mathrm{Ph}$, fine band, silt and clay show an increase in value with age of the plantations, while the bulk density and coarse-sand fraction show a decrease value with age of plantation. Similarly, Bohre and Chaubey (2014) observed that plantation of sir species of plants - Dalbergia Sissoo, Pongamia Pinnata, Tectona grandis, Gmelina Arborea, Azaadirachta indica and Cassia Siamea were able to restore the degraded coal fields of Singrauli, India.

Two dominant tree species-Tectona grandis (teak) and Limelina have proven to restore the fertility of soil in the Gidan Waya reserve so far. A 25 years old Tectona grandis plantation in this area has confirmed that the fertility of soil in this environment could be restored. We therefore advocate the planting of these two exotic species of trees that will cost the famers less effort compared to other methods of restoration in order to achieve environmental sustainability. Environmental education should be provided to the farmers on best agricultural practices and the planting of trees in order to check landscape degradation.

\section{Conclusion}

The importance of afforestation using exotic species lies in their ability to become established faster than indigenous ones. Based on the observation of the soil physical properties in terms of crop yield where the two dominant tree species were planted, it is very clear that afforestation using them in Gidan Waya reserve could bring about a rapid change in soil properties, especially the chemical properties. Hence the policies makers and stakeholders of environmental management and conservation should make use of these advantages to check the ever increasing deterioration of our non-expanding soil resources. 


\section{References}

Apfelbaum, S. I. \& Chapman, K. A., (1994) Ecological Restoration: A Practical Approach. C:49:083094. Pp1 -17.

Arnalds, A., (2005) Combating Climate Change by Restoration of Degraded Land. Soil Conservation Service of Iceland. Paper Presented at a Dinner in Honour of Former US. Vice-President, Mr. Al Gore; April $7^{\text {th }} 2008$

Bagudu, N., (2009) Land Desecration and Environmental Degradation on Nigeria's Jos Plateau. League for Human Right Publication pp37- 42

Bai, Z.G. \& Dent, D. L., (2013) "Global Assessment of Land Degradation and Improvement 2. Identification by Remote Sensing". Report 2010/02. FA O/ISRIC. ROME. Chapter 4.

Bohre, P. \& Chaubey, D. P., (2014) Restoration of Degraded Lands Through Plantation Forests. State Forest Research Institute. Global Journal of Science Frontier Research Vol. 14 Issue 1 Version 1.0.

Bradshaw, A. D., (1995) Underlying Principles of Restoration. Canadian Journal of Fisheries and Aquatic sciences 53 (suppl 1): 3- 9.

Dogo, B. J., (1992) Soil Fertility Restoration by Way of Afforestation in Nigerian Semi-Arid Area. Unpublished Undergraduate Project in the Department of Geography. Ahmadu Bello University, Zaria. Pp $12-38$

Enger E. D. \& Smith, B. F., (2004) Environmental Science: A study of interrelationships. New York. Mc Grawhill publishers. ISBN 0 - 07 - 291987- 6. Pg $36-369$.

F.A.O., (2003). Land Degradation Assessment in Drylands. Brochure, UN Food and Agriculture Organisation: Rome [ftp://.fao.org/agl/agll/docs/lada.pdf]

Gishadottir, G., \& Stocking M., (2005) Land Degradation Control and its Global Environmental Benefits. Published online by John Wiley and Sons Ltd 16:99 -1, 2.

Global Environmental Facility, (2010) Land Degradation as a Global Environmental Issue: a synthesis of three studies commissioned by GEF to strengthen the knowledge Base to support the Land degradation focal Area. GEF/c.30/inf.8.

International Atomic Energy Agency, (1998), Factors for Formulating Strategies for Environmental Restoration. IAEA-TEC DOC- 1032 Pg. 2 - 5

Nachtergaele, F., Biancalani, R. \& Petri, M., (2005) Land degradation. SOLAW Background Thematic Report 3.

UN / FAO, (2005) Global Forest Resources Assessment 2005. Progress Towards Sustainable Management. Forestry paper 147. Rome.

UNFCCC, (2006) Restoration of Degraded Lands Through Afforestation/ Reforestation. Approved Afforestation and Reforestation Baseline. Methodology AR-Am0002. Version 01 . Sectoral scope: 14. http://cdm/Unfccc.int/methodologies/ARmethodologies /process?openNM=ARNM00078 Single=1. Accessed15jully2014.

World Meteorological Organization (2005). Climate and Land Degradation. WMO NO. 989. 